\title{
Suçun Önlenmesinde Hapis Cezası ile Seçenek Yaptırımların Etkinliğinin Karşılaştırılması: Meta-Analiz Çalışmalarının Sistematik Olarak İncelenmesi
}

\section{Comparing the Effects of Imprisonment and Alternative Sanctions on Crime Prevention: Systematic Review of Meta-Analysis Studies}

\section{Buket ABANOZ1}

${ }^{1}$ Öğretim Görevlisi, Fatih Sultan Mehmet Vakıf Üniversitesi, İstanbul, Türkiye

öz

Bu çalışmada, kısa süreli hapis cezası ile seçenek yaptırımların mükerrer suçluluğun önlenmesi üzerindeki etkisi ampirik bulgular eşliğinde değerlendirilmiştir. Çalışmada metot olarak arama, Campbell İşbirliği'nin sistematik derlemeler kütüphanesi ve Google akademik üzerinden sistematik olarak gerçekleştirilmiştir. Çalışmanın sonucunda, araştırmada belirlenen kriterlere göre hapis ve seçenek yaptırımların mükerrer suçluluğun önlenmesi üzerindeki etkisini değerlendiren üç meta-analiz çalışması tespit edilmiştir. Üç çalışmada da seçenek yaptırımların, hürriyeti bağlayııı cezalara nazaran tekrar eden suçluluğun önlenmesinde daha etkili olduğuna, fakat bu etkinin kayda değer bir büyüklükte olmadığına ilişkin bulgular ortaya koyulmaktadır. Bununla birlikte, bir çalışmada hapis cezasının mükerrer suçluluğun önlenmesinde istatistiksel olarak anlamlı bir etkiye sahip olmadığı, bilakis tekrar eden suçluluğun artmasına neden olduğu görülmektedir. Çalışmada bulguların teori, uygulama ve bilimsel araştırmalar açısından doğurduğu sonuçlar tartışılmaktadır.

Anahtar Kelimeler: Hapis cezası, kısa süreli hapis cezası, seçenek yaptırım, alternatif yaptırım, suçun önlenmesi, mükerrer suçluluk, sistematik derleme

\section{ABSTRACT}

This study aims to systematically review the results of research on the effect of short-term imprisonment and alternative sanctions on preventing recidivism. The systematic review in this study was carried out using resources at the Campbell Collaboration Library of Systematic Reviews and Google Scholar. Three meta-analytic studies about the effect of shortterm imprisonment and alternative sanctions on preventing recidivism met the eligibility criterias set forth for this systematic review. These three studies include evaluations carried out between 1960 and 2013. All three meta-analytic studies suggest that alternative sanctions are more effective at preventing recidivism than imprisonment. However, the level of effectiviness is not significant. These three studies indicate that imprisonment does not have a statistically significant effect in preventing reoffense. Furthermore, one of three studies indicates that imprisonment actually has an adverse effect on preventing recidivism.

The following questions are discussed in this study: Can the finding that alternative sanctions are more effective than imprisonment on preventing recidivism be generalized across all alternative sanctions? In addition, is it possible to draw conclusions as to which alternative sanctions are more effective than others? Finally, can these findings guide the evaluation of the Turkish criminal justice system? The results of these findings are discussed in terms of theory, practice, and research.

Keywords: Prison sentence, custodial sanction, non-custodial sanction, alternative sanction, crime prevention, recidivism, systematic review

Date of receipt: $23.06 .2016 \cdot$ Date of acceptance: 26.12 .2016

Corresponding author: Buket Abanoz, E-mail: buket-abanoz@hotmail.com

Citation: Abanoz, B. (2017). Suçun önlenmesinde hapis cezası ile seçenek yaptırımların etkinliğinin karşılaştııılması: Meta-analiz çalışmalarının sistematik olarak incelenmesi. Ceza Hukuku ve Kriminoloji Dergisi-Journal of Penal Law and Criminology 2017; 5(2):1-28. https://doi.org/10.26650/JPLC360264 


\section{EXTENDED ABSTRACT}

This study aims to systematically review the available research on the effect of short-term imprisonment and alternative sanctions on preventing recidivism. The systematic review in this study was carried out using resources at the Campbell Collaboration Library of Systematic Reviews and Google Scholar. These databases were searched using the following keywords: imprisonment, prison sanction, shortterm imprisonment versus alternative sanctions, custodial versus non-custodial sanctions, formal sanctions versus immediate sanctions, recidivism, reoffending, victim, systematic review, meta-analysis, random controll. The author searched referenced lists, and conducted electronic searches for all reports that used these particular terms. However, only studies written in English and Turkish were considered for this systematic review.

In order to be included in this systematic review, the meta-analytic evaluation studies fulfilled the following criteria: (1) All of them had at least one control or comparison group. (2) All of them had control and experiment groups consisting of people who were sentenced to imprisonment and alternative sanctions. (3) The interventions were homogenous; in other words, either prison sanctions or alternative sanctions were applied for the control and experimental groups. (4) All of the studies measured, the recidivism rate after imprisonment and alternative sanctions. That isi if a study compared only the execution cost of imprisonment and alternative sanctions, it was not included in this systematic review (McDougall et all, 2008). However, in a meta-analytic study, more than one measurement can be conducted. If the effect of prison and alternative sanctions on recidivism was clear and separate in the study, the study was included in this systematic review. (5) The results of the included studies in this systematic review were examined using metaanalytical methods.

Three meta-analytic studies (Nagin et al, 2009; Jonson, 2010; Villettaz et al, 2015) about the effect of short-term imprisonment and alternative sanctions on preventing recidivism met the eligibility criterias set forth in this systematic review. These three studies include evaluation studies carried out between 1960 and 2013. All three studies are connected with each other because the evaluation studies they contain the same evaluation studies. The author draws some conclusions based on the findings from these three meta-analytic studies. First, it appears that the number of systematic reviews assessing the impact of imprisonment and alternative 
sanctions on recidivism is scarce. However, the number of evaluation studies is rather high. Researchers prefer to compare the prison sentence with one or more alternative sanctions rather than conducting systematic review. Second, this systematic review reveals findings that alternative sanctions are more effective than imprisonment in preventing recidivism. All three meta-analytic studies suggest that alternative sanctions are more effective than imprisonment on preventing recidivism. However, the level of this effectiviness is not significant. These three studies indicate that imprisonment does not have a statistically significant effect on preventing reoffense. Furthermore, one meta-analytic study indicates that imprisonment has an adverse effect on preventng recidivism (Jonson, 2010). These findings contradict the theory of deterrence, which suggests that imprisonment is the most effective method of preventing crime. However, it should not be overlooked that criminals in the control group who were sentenced to imprisonment were in a certain risk group and committed certain crimes. The experimental group consisted of criminals who committed crimes that could be converted to alternative sanction. In legal systems, short-term prison sentences (generally 6-12 months) are converted to alternative sanctions. Therefore, the finding that alternative sanctions are more effective than imprisonment only applies to short- term imprisonment. Third, can the findings that alternative sanctions are more effective than imprisonment on preventing recidivism be generalized to all alternative sanctions? In addition, is it possible to conclude as to which alternative sanctions are more effective than the others? Fourth, can the findings serve as a guide for Turkey's criminal justice system? The results of the findings in this study are discussed in terms of theory, practice and research.

\section{Hapis Cezası ve Seçenek Yaptırımlar}

5237 sayılı Türk Ceza Kanunu'nun 45. maddesinde, yaptırımların cezalar ve güvenlik tedbirlerinden oluştuğu; cezaların ise hapis ve adli para cezası olduğu belirtilmiştir. Hapis cezaları başlıklı 46. maddede ise ağırlaştırılmış müebbet, müebbet ve süreli hapis cezaları sıralanmış, devam eden maddelerde de bunlar tanımlanmıştır. Süreli hapis cezası, bir aydan az yirmi dört yıldan fazla olamazken (TCK m. 49/1); hükmedilen bir yıl veya daha az süreli hapis cezası ise kısa süreli hapis cezasıdır (TCK m.49/2). Bunun dışında, 5271 sayılı Ceza Muhakemesi Kanunu'nun 2. maddesinde "Kısmî bir düzeni korumak amacıyla yaptırım altına alınmış olan fiil dolayısıyla verilen, seçenek yaptırımlara çevrilemeyen, ön ödeme uygulanamayan, 
tekerrüre esas olmayan, şartla salvverilme hükümleri uygulanamayan, ertelenemeyen ve adlî sicil kayıtlarına geçirilmeyen hapsi ifade eder" denilerek disiplin hapsinin tanımlandığı ve özellik arz eden bir başka hapis türünden bahsedildiği de görülmektedir.

Bununla birlikte, hürriyeti bağlayıcı yaptırım (custodial sanction) şeklinde karşımıza çıkan yaptırım türü, kişiyi özgürlüğünden mahrum bırakan ve kapalı bir yerde tutulmasına neden olan her türlü cezai tepkidir. Mükerrer suçluluğu ölçen araştırmalarda da sadece hapis ve kısa süreli hapis cezası değil; hafta sonu veya günün belli saatlerinde dışarı çıkılmasına izin verilip verilmediğinin önemi olmaksızın ev dışında herhangi kapalı bir yerde tutulmayı öngören bütün yaptırımların dâhil edildiği görülmektedir (ör. Gottfredson \& Barton, 1993). Örneğin, Amerika'da uygulanan askeri kamp (boot camps) tarzı ağırlaştırılmış infaz yöntemleri, derhal tutuklama (immediate detention) şeklinde adlandırılan aile içi şiddet gibi suçlarda uygulanan yaptırımlar.

Seçenek yaptırımlar ise tersinden hareketle hürriyeti bağlayıcı olmayan yaptırım (non-custodial veya alternative sanction) şeklinde karşımıza çıkmaktadır'. Seçenek yaptırımlar, kişiyi özgürlüğünden mahrum bırakmayan kamuya yararlı bir işte çalıştırılma, elektronik izleme, para cezası gibi hapsetme harici ceza hukuku yaptırımlarıdır. Tedaviye yönelik birçok programı da içine alabildiği için bu yaptırım türünün kapsamı oldukça geniştir.

Seçenek yaptırımlar, 5237 Sayılı Türk Ceza Kanunu'nun 50. maddesinde; a) Adlî para cezası, b) Mağdurun veya kamunun uğradığı zararın aynen iade, suçtan önceki hale getirme veya tazmin suretiyle, tamamen giderilmesi, c) En az iki y1l süreyle, bir meslek veya sanat edinmeyi sağlamak amacıyla, gerektiğinde barınma

1 Yabancı literatürde alternative sanction (alternatif veya seçenek yaptırım), non-custodial (hürriyeti bağlayıcı olmayan yaptırım) şeklinde karşımıza çıkan söz konusu yaptırım türleri, Türk Ceza Kanunu m. 50'de düzenlenen "kısa süreli hapis cezasına seçenek yaptırım” başlığı altında düzenlenen yaptırım türleriyle tam olarak uyuşmamaktadır. Örneğin, TCK'da denetimli serbestlik bir seçenek yaptırım türü olarak düzenlenmemiş olmasına rağmen, hapis cezası ile seçenek yaptırımların suçun önlenmesi üzerindeki etkisini değerlendiren etkinlik çalışmalarında denetim serbestliğin (probation) hapis cezası ile karşılaştırıldığı görülmektedir. Benzer şekilde "tutuklama" bir yaptırım türü değil, koruma tedbiri olmasına rağmen etkinlik çalışmalarında seçenek yaptırım türleri ile mukayese edilmektedir. Dolayısıyla çalışmalarda kıstas alınan husus, yaptırım türü olup olmamasından ziyade suç teşkil eden haksızlığa karşı verilen tepkinin hürriyeti bağlayıcı olup olmadığıdır. Nitekim seçenek yaptırım türleri arasında kısa süreli hapis cezasına seçenek olmakla beraber müstakil ceza olarak uygulanan yaptırım türleri de yer almaktadır. Bununla birlikte, TCK'da seçenek yaptırım ifadesine yer verilmiş, doktrinde de genel olarak söz konusu ifade yerleşmiş bulunmaktadır. Bu nedenle söz konusu nüans burada belirtilmekle beraber çalışmada seçenek yaptırım ifadesinin kullanımı tercih edilmiştir. 
imkânı da bulunan bir eğitim kurumuna devam etme, d) Mahkûm olunan cezanın yarısından bir katına kadar süreyle, belirli yerlere gitmekten veya belirli etkinlikleri yapmaktan yasaklanma, e) Sağladığı hak ve yetkiler kötüye kullanılmak suretiyle veya gerektirdiği dikkat ve özen yükümlülüğüne aykırı davranılarak suç işlenmiş olması durumunda; mahkûm olunan cezanın yarısından bir katına kadar süreyle, ilgili ehliyet ve ruhsat belgelerinin geri alınması, belli bir meslek ve sanatı yapmaktan yasaklanma, f) Mahkûm olunan cezanın yarısından bir katına kadar süreyle ve gönüllü olmak koşuluyla kamuya yararlı bir işte çalıştırılma şeklinde sıralanmıștır.

\section{Hapis Cezası ve Seçenek Yaptırımların Arka Planındaki Teoriler}

Ceza adalet sistemindeki her bir politikanın arkasında, -biz fark etsek de etmesek de- esasında bir kriminoloji teorisi bulunmaktadır (Akers \& Sellers, 2009: 2, 11; Topçuoğlu, 2015 (a)). Her ne kadar sosyal bilimlerde teori kavramı, zihinlerde genel olarak gerçekleri yansıtmayan ve işe yaramayan bir beyin jimnastiği şeklinde olumsuz bir çağrışıma neden olsa da teori, doğru bir şekilde geliştirilirse gerçek durumlar, insan davranış1 ve deneyimiyle ilgilidir (Akers \& Sellers, 2009: 1). Etkili bir teori, hâli hazırda bildiğimiz olgulardan anlam çıkarmamıza yardımcı olduğu gibi, yeni olgular karşısında da test edilebilmektedir (Akers \& Sellers, 2009:1). Eğer bulgular, teorinin önermeleriyle çelişkili olursa, bu durumda teori yanlışlanabilir. Aksi durumda da teorinin güvenilirliği artacak ve fakat ispatlandığı söylenemeyecektir.

Bununla birlikte, burada sorulması gereken soru, ceza adalet sistemindeki herhangi bir uygulamanın bir teoriye dayanıp dayanmadığı değildir. Çünkü zaten dayanmaktadır. Asıl sorulması gereken soru, uygulanan politikaların ve bu politikaların dayandığı teorilerin ampirik olarak ne kadar güvenilir ve geçerli olduğudur (Akers \& Sellers, 2009: 11). Zira suçla mücadelede bilimsel destekten yoksun günübirlik politikalarla başarıya ulaşabilmek mümkün değildir. İşe yaradığ1 bilimsel olarak ortaya koyulan, kanıta dayalı politikalarla elde edilen ve elde edilmek istenen sonuç arasındaki fark kapanacaktır (Topçuoğlu, 2015(a): 2). Bu çalışmada, öncelikle, ideal suç önleme yöntemi olarak hapsetmeyi öneren Rasyonel Tercih Teorisi ve Caydırıcılık Teorisine ve bu teorilerin geliştirildiği Klasik Okul'a bakılacak; ardından, seçenek yaptırımların arka planındaki Damgalama Teorisi, Sosyal Öğrenme ve Sosyal Bağ Teorileri sınırlılıkları da ortaya koyularak incelenecektir. 


\subsection{Hapis Cezası: Klasik Okul, Rasyonel Tercih Teorisi ve Caydırıcılı Teorisi}

Hapis cezas1, Rasyonel Tercih ve Caydırıcllı Teorilerine, bu teorilerin geliştirildiği Klasik Okul'a dayanmaktadır. Klasik Okul'la birlikte, Ortaçağ'ın zalimane cezalandırma yöntemleri yerini, insanlara yaptıklarının kötü olduğunu anlatacak ve pişman olmalarını sağlayacak rasyonel ve adil bir cezalandırma sistemine bırakmıştır (Akers \& Sellers, 2009: 17). Zira bu dönemde insan onurlu bir varlık olarak görülmüş, devletin cezalandırma yetkisi ise sosyal sözleşmeye dayandırılmıştır (White \& Haines, 2008: 23). Bu sözleşmede, bireyler maddi ve manevi varlıklarını geliştirmek için birtakım haklarından vazgeçmekte ve devlet de karşıllı̆ında onların güvenliklerini sağlamakta ve haklarını korumaktadır (White \& Haines, 2008: 23).

Klasik Okul'a göre; insan bencil, hedonist ve rasyonel bir varlıktır. Suçun nedeni de insanın kendini düşünmesi, zevklerini ve hazlarını arttırmak, acılarını ve sıkıntılarını azaltmak için bir arayış içinde olmasına dayanmaktadır. İşte bu noktada, insan suç işlemeden önce elde edeceği fayda ile maruz kalabileceği zararın hesabını rasyonel bir şekilde yaparak, suç işlemeyi veya kurallara uymayı tercih etmektedir (Akers \& Sellers, 2009: 18). Eğer maruz kalacağı acı ve yaptırım, elde edeceği haz ve faydadan daha fazla ise suç işlemeyecektir. Söz konusu rasyonel muhakeme de genellikle geçmiş cezalandırma tecrübelerine bakılarak yapılmaktadır (Akers \& Sellers, 2009: 18).

Klasik Okul'a göre cezanın en temel amacı, caydırıcılıktır. Suçu önlemenin en kestirme yolu ise cezalar yoluyla suçun maliyetlerini arttırarak suçu rasyonel bir tercih olmaktan çıkarmaktır (Akers \&Sellers, 2009: 18). Bu bakımdan, öncelikle ceza suça uygun olmalıdır. Bu daha sonra failin yaşı, zihinsel durumu gibi birtakım kriterlere de uygun olması şeklinde değiştirilmiştir (Akers \& Sellers, 2009: 19). Ayrıca cezaların caydırıcılığı sanıldığının aksine cezanın sadece şiddetine değil; kesinliğine ve çabukluğuna da bağlıdır (Beccaria, 2013: 101-103; Akers \& Sellers, 2009: 18-19). Bu noktada iki çeşit caydırıcılık söz konusudur. İlki, eğer suç işleyen kişi derhal (çabukluk) yakalanır (kesinlik) ve uygun bir şekilde cezalandırılır (şiddet) ise, bu tecrübe onun bir daha suç işlemesine engel olur. Fakat yakalanmadan veya cezalandırılmadan sık sık suç işleyen insanın risk algısı düşük olacaktır ve yeniden suç işleme ihtimali de artacaktır. Kriminolojide bu özel caydırıcılık olarak adlandırılmaktadır. İkincisi ise, henüz suç işlememiş insanların suçun karşılığında verilen cezayı görmeleri, korku ve yaptırım tehdidiyle yüzleşmeleri onları suç işlemekten alıkoyacaktır. Bu da genel caydırıcılıktır. Cezaların kesinliği, şiddeti ve 
çabukluğu, orantılılı̆̆ı, genel ve özel caydırıcılık aslında modern caydırıcılık teorisinin temellerini ve modern ceza hukuku ve ceza adalet sisteminin de kalbini oluşturmaktadır (Akers \& Sellers, 2009: 19-20). Bu noktada hapis cezasiyla, bir yandan suçlu alıkonularak yeni bir suç işlemesi engellenmekte, aynı zamanda hak edilen ceza tatbik edilerek adaletin tesisi sağlanmakta; diğer taraftan ise hem toplum mahkûmdan korunmakta hem de potansiyel failler yaptırım tehdidiyle yüzleştirilmektedir. Bu bakımdan hapis cezası, Klasik Okul'un ideal cezalandırma yöntemidir.

Bugünkü anlamda hükümlüyü topluma yeniden kazandırma amacına dayalı ve belirli bir hukuki çerçeveye oturtulmuş ilk hapishanenin 1595 yılında Amsterdam'da inşa edildiği söylenmektedir (Erdem, 1993: 193). Her ne kadar ilk kurulduğunda Hollanda dışında fazlaca taraftar bulamasa da hapis cezası günümüzde bütün yarg1 sistemlerinde cezai yaptırım sisteminin belkemiğini oluşturmaktadır. Bununla birlikte, hapis cezasının ilk ortaya çıkışından günümüze kadar geçen sürede, dünya genelinde artan hapishane nüfusu ve tekerrürün istikrarla artış göstermesi, hapsetmenin, cezanın amacını gerçekleştirmeye en uygun yaptırım türü olup olmadığının sorgulanmasını sağlamıştır. Kısa süreli hapis cezası da ceza adalet politikası tartışmalarının odağında bulunmaktadır. Bunun iki önemli sebebi olduğu söylenebilir. İlki, infaz kurumunda kalınan sürenin, ıslah programlarının uygulanabilmesi için çok kısa olması; ikincisi ise suçun normalleşmesi, kanıksanması, yeni suç tipleri ve suç işleme taktikleriyle tanışmak için bu sürenin çok uzun olmasıdır (İçel ve diğerleri, 2000: 94). Bunun dışında hapis cezasının kendine özgü sakıncaları da bulunmaktadır. İlki, hapis cezasının infaz maliyetlerinin devlete ciddi ekonomik külfetler yüklemesidir. İkincisi ise, hapishaneye giren mahkûmun ailesinden, iş çevresinden, sosyal ilişkilerinden kopartılarak damgalanması, maddi ve manevi yönden zayıflamasıdır (Güvel, 2004: 28-29). Bu noktada, dünya genelinde, hapis cezasının sakıncalarını gidermeye yönelik olarak hapsetmenin sınırlandırılması ve seçenek yaptırımlara hükmedilmesi ile hürriyeti bağlayıcı ceza dışındaki infaz biçimlerinin geliştirilmesi eğilimi güç kazanmaktadır (Erdem, 1993: 194). Bununla beraber bilhassa suçluyu toplum dışına itmeyen denetimli serbestlik, kamuya yararlı bir işte çalıştırılma ve elektronik izlemenin ön plana çıktığı söylenebilir.

\subsection{Seçenek Yaptırımlar: Damgalama, Sosyal Öğrenme ve Sosyal Bă̆ Teorileri}

Seçenek yaptırımların arka planındaki teorilerden ilki, toplumsal tepki perspektifi olarak da bilinen, geleneksel suç teorilerinin aksine doğrudan suçun nedenleri yerine, 
toplumun suç ve suçlu üzerinde gösterdiği tepkiler üzerine yoğunlaşan Damgalama Teorisidir (Labeling Theory) (Akers \&Sellers, 2009: 151; White \& Haines, 2008: 74). Bu teoriye göre, kişinin bir kez suç işledikten sonra tekrar suç işleyip işlemeyeceği tamamen bu kişiye nasıl bir tavır takınılacağına bağlıdır. Charles Horton Cooley (1902) ve George Herbert Mead (1934), bireylerin kendilerine dair bilgiyi çoğu zaman yüz-yüze sosyal etkileşimler neticesinde elde ettiklerini ve davranışlarını dış dünyadan gelen tepkilere göre şekillendirdiklerini "sembolik etkileşim" kavramsallaştırmasıyla ortaya atan ilk isimlerdir (Akers \& Sellers, 2009: 152). Cooley, bunu "aynaya bakmak" (looking-glass self) deyimine benzetmektedir; bireyler de tıpkı bir ayna gibi diğer insanların kendileri hakkında ne düşündüklerine bakarak, kendilerine bir değer biçmekte ve diş dünyadan gelen olumsuz betimlemeleri benimseyebilmektedir (Cooley, 1902; Akers \& Sellers, 2009: 152). Ceza adalet sistemi ve toplum tarafından kişinin "suçlu", "keş", "katil” "cani” veya "zanlı" olarak damgalanması, hatalarının ve kusurlarının yüzüne vurularak marjinelleştirilmesi, kişiyi toplumdan kopararak suçlu bir alt kültürün parçası haline getirebilir ve bu kişinin suç işlemeyi bir kariyer olarak benimsemesine yol açabilir (Akers \& Sellers, 2009: 153; White \& Haines, 2008: 75).

Damgalama teorisinin suçun önlenmesi noktasında önerdiği politikalar, bazı eylemlerin suç olmaktan çıkarılması (decriminalization) ve hapishanelerin boşaltılması (decarceration) gibi müdahale etmemeden (non-intervention) başlayıp başta suçlu olmak üzere toplumun katılımıyla suçun neden olduğu olumsuz etki, zararın ve hasarın giderilmesi (restitution and reparation), örneğin, çocuk suçluların bir özel kuruma yönlendirilmeleri, terapi grupları, komşuluk programları, eğitim programları gibi çeşitli müdahale (intervention) yöntemlerine kadar çok geniş bir yelpazede uzanmaktadır (Akers \& Sellers, 2009; White \& Haines, 2008: 75-76). Bununla birlikte, damgalama teorisi de ciddi eleştirilere maruz kalmaktadır. $\mathrm{Bu}$ teoriye yönelik en güçlü eleştirilerden ilki, kişilerin birincil sapma davranışlarını neden işledikleri ve kişileri suça iten faktörlerin neler olduğuyla ilgilenmemesidir (Einstadter \& Henry, 1995: 224). İkincisi ise, teorinin başında aktif bir rol oynayarak, bilerek ve isteyerek suç işleyen kişinin, teorinin sonlarına doğru tamamen edilgen, kendisine vurulan damgadan sonra kontrolünü ve inisiyatifini kaybeden biri haline dönüşmesidir (Einstadter \& Henry, 1995: 224).

Seçenek yaptırımların arka planındaki teorilerden diğeri, Sosyal Öğrenme (Social Learning) Teorisidir. Ronald L. Akers tarafindan ortaya atılan bu teori, kriminoloji 
teorileri arasinda lider konumda olan ve bugüne kadar ampirik olarak en fazla test edilen (örn: Stitt \& Giacopassi, 1992) teoridir (Ellis \& Walsh, 1999; Akers \& Sellers, 2009: 85). Akers'in bu teorisi, aslında Edwin H. Sutherland'in Ayırıcı Birliktelikler Teorisi'nin (differential association theory) geliştirilmiş ve davranışsal açıdan yeniden formüle edilmiş halidir (Akers \& Sellers, 2009: 85). Sutherland, suçun tıpk1 diğer davranışlar gibi öğrenilen bir davranış olduğunu ve bu öğrenmenin bireyin sokakta tesadüfen karşılaştığ 1 kişilerle olan etkileşimi sonucunda değil; bireyin kendisi açısından önemli olan insanlarla olan etkileşimi sonucunda gerçekleştĭgini savunmaktadır (Akers \& Sellers, 2009: 86-87). Akers de normlara uyma ve normlardan sapma davranışını aynı öğrenme süreci ile açıklamaktadır. Fakat Akers öğrenme sürecine ayırıcı pekiştirme olarak ifade edilen (differential reinforcement) bir unsur daha ilave ederek, dört temel kavram üzerinden izah etmişsir: Ayırıcı Birliktelikler (differential association), Tanımlar (definitions), Ayırıcı Pekiştirme (differential reinforcement) ve Taklit (imitation) (Akers \& Sellers, 2009: 89-90). Eğer birey, sapma gösteren kişilerle ayırıcı olarak birlikte olursa, kişilerin sapma davranışına ilişkin tanımlamaları olumlu olursa, sapma davranışı ayırıcı olarak daha çok pekiştirilirse ve insanlar sapma gösteren modellere daha fazla maruz kalırsa normları ihlal eden davranış ortaya çıkacaktır (Akers \& Sellers, 2009: 93). Sosyal öğrenme süreci ile suçun açıklanması ampirik olarak güçlü desteğe sahiptir. Sosyal öğrenme teorisini test eden çalışmaların büyük çoğunluğunda teorinin öngördüğü gibi değişkenlerin suçu tahmin eden en güçlü faktörler olarak ortaya koyulduğu görülmektedir (Ör. Winfree ve diğerleri, 1993; Skinner \& Fream, 1997; Durkin ve diğerleri, 2005). Akers'in teorisi kendi yaptığı çalışmalar ve danışman olduğu tezlerle de test edilmiş ve farklı suç tiplerini açılama noktasında geçerliliği desteklenmiştir (Boeringer ve diğerleri, 1991; Lee ve diğerleri, 2004; Akers \& Sellers, 2009: 104).

Sosyal öğrenme teorisi çerçevesinde suçun önlenmesine ilişkin çeşitli programlar önerilmektedir. Örneğin, çocukluktan itibaren şiddet ve antisosyal içerikli davranış modellerinin çocuğa gösterilmesinden kaçınılması ve uygun rol modellerinin oluşturulması; çocuklarda kişilik gelişimini hedef alan (aile ve akran gruplarını da kapsayan) çeşitli rehabilitasyon programları; mahkumların hapishanede birbirinden farklı suç türlerini ve suç işleme metotlarını öğrenmelerini engellemek amacıyla mümkün olduğunca tek kişilik veya iki kişilik hücrelerde tutulmaları ve denetimli serbestlikte, ister çocuk ister yetişkin olsun, davranış değişikliği odaklı programlar gibi (Akers \& Sellers, 2009: 110 vd.) 
Seçenek yaptırımların arka planındaki teorilerden bir diğeri ise, Sosyal Bă̆ (Social Bonding) Teorisidir. Hirschi'in geliştirdiği (1969) sosyal bağ teorisi, kendinden önceki sosyal kontrol teorilerinin birçok unsurunu bir araya getirmiş ve suçluluğu farklı bir şekilde izah etmiştir (Akers \& Sellers, 2009: 128-129). Bu teoriye göre, bir kişinin toplumla olan bağı zayıfladığında ya da kopma noktasına geldiğinde suç işleme ihtimali artmaktadır. Kişinin toplumla olan bağını ise dört temel unsur meydana getirmektedir: Bağlılık (attachment to others), adanmışlık (commitment), sürekli meşguliyet (involvement) ve inançlar (belief) (Akers \& Sellers, 2009: 129-132). Kişinin ailesi, arkadaşları, okul öğretmeni ve diğer kimselerle arasındaki toplumsal bağı meydana getiren bu unsurlar ne kadar güçlü olursa, kişi normlara uyma yönünde o derece güçlü olarak kontrol altında tutulacaktır. Tersinden hareketle, bu unsurlar ne kadar zayıflarsa, kişinin normları ihlal etme olasılığı o kadar güçlü olacaktır. Hirschi, toplumsal bağı oluşturan bu dört unsurun birbiriyle bağlı olduğunu, bu nedenle biri zayıfladığında diğer unsurların da zayıflayacağını iddia etmektedir (Akers \& Sellers, 2009: 129). Yapılan ampirik çalışmalar, sosyal bağ teorisini genel olarak desteklemektedir (Akers \& Sellers, 2009: 132).

Sosyal bağ teorisinin suçun önlenmesine ilişkin öne sürdüğü politikalar, kişinin toplumsal bağlarını kuvvetlendirmeye yöneliktir. Bu teorinin suç davranışını açıklarken ortaya koyduğu dört temel unsurdan yola çıkarak; çocukların aile ve okulla olan bağ lılığını kuvvetlendirmeye (bağlılık), çocuğun okulda başarılı olmasını sağlamaya (adanmışlık), çocukları faydalı işlerle meşgul etmeye ve zamanlarını olumlu faaliyetlerde harcamalarını teşvik etmeye (sürekli meşguliyet) ve de çocuklara ve gençlere toplumsal değerleri öğretmeye (inançlar) yönelik programlar ve uygulamalar önerilmektedir (Akers \& Sellers, 2009).

\section{Suçun Önlenmesinde Hapis Cezası İle Seçenek Yaptırımların Etkinliğinin Karşılaştırılması}

Her şeyden önce, bütün araştırmaların, metodolojik ve bilimsel açıdan aynı kalitede olmadığ kullanılan tasarım ve metot özellikleri, araştırma örnekleminin özellikleri, katılımcıların özellikleri gibi önemli farklılıkları dikkate almadan mevcut çalışmaların sistematik olmayan bir literatür derlemesinin yapılması yanıltıcı sonuçların ortaya çıkmasına neden olmaktadır (Topçuoğlu, 2016: 91-92). Bu nedenle araştırmacılar, daha doğru ve objektif bir değerlendirme yapabilmek için sistematik derleme 
çalışmaları yapmaktadır (ör. Bennett ve diğerleri, 2008; Topçuoğlu, 2016). Çünkü sistematik derlemeler, birçok açıdan sistematik olmayan literatür derlemelerinden ayrılmaktadır. Bunları şöyle sıralamak mümkündür (Farrington \& Petrosino, 2001; Littell ve diğerleri, 2008: Topçuoğlu, 2016: 92-93):

1. Sistematik derlemeye dâhil edilecek olan etkinlik değerlendirmesi çalışmalarının hangi kriterler açısından değerlendirilip çalışmaya dâhil edileceği çok şeffaf olarak ortaya koyulmalıdır.

2. Çalışmalara nasıl ulaşı1dığı, aramada kullanılan kelimeler, aramanın gerçekleştirildiği veri tabanları, dergiler ve diğer kaynaklar ayrıntıları ile belirtilmelidir.

3. Araştırmacı elde ettiği tüm çalışmaları başlangıçta belirlediği kriterler doğrultusunda tek tek inceleyerek en sonunda elde ettiği bulguları betimsel olarak sunabileceği gibi (sistematik derleme), çeşitli istatistik yöntemler kullanılarak niceliksel olarak da sunabilmektedir (meta-analiz çalışması) (Farrington \& Petrosino, 2001; Littell ve diğerleri, 2008: Topçuoğlu, 2016: 92-93).

$\mathrm{Bu}$ çalışma, aşağıda yöntem bölümünde ortaya koyulan kriterler ışığında, suçun önlenmesinde hapis cezası ile seçenek yaptırımların etkisi üzerine yapılmış metaanaliz çalışmalarını özetleyen bir sistematik derleme çalışmasıdır.

\subsection{Yöntem}

$\mathrm{Bu}$ çalışma, bugüne kadar yapılan hapsetme ve seçenek yaptırımların suçun önlenmesi üzerindeki etkisini değerlendiren meta-analiz çalışmalarını bütüncül olarak ele almayı ve sistematik derlemesini yapmayı amaçlamaktadır. Bir başka deyişle, önceki meta-analiz çalışmaları üzerinden gerçekleştirilen daha kapsamlı bir sistematik derleme çalışmasıdır. Bu sistematik derlemeye dâhil edilebilmesi için önceki çalışmaların içerdikleri ampirik çalışmaların seçiminde aşağıdaki kıstasların yerine getirilmiş olması gerekmektedir:

(1) Dahil edilen çalışmaların içindeki etkinlik çalışmaları mutlaka en az bir kontrol ya da karşılaş̧tırma grubuna sahip olmalıdır. Herhangi bir kontrol grubu kullanmayan yani sadece tek bir grup üzerinde müdahale öncesi ve sonrası ölçüme dayanan etkinlik değerlendirmesi çalışmalarını dâhil eden sistematik derlemeler kapsam dışında tutulmuştur. 
(2) Bütün çalışmalarda, kontrol ve deney grubu, hapis cezası ve seçenek yaptırıma tabi tutulan kişilerden oluşmalıdır. Bu çalışma, genel olarak hapis cezası ile seçenek yaptırımın mükerrer suçluluk üzerindeki etkisini değerlendirmeyi hedeflediğinden hapis cezası veya seçenek yaptırımdan herhangi birinin kendi arasındaki etkinliğini değerlendiren sistematik derlemeler çalışmaya dâhil edilmemiştir. Örneğin, sadece hapsetme, infaz çeşitleri veya hapsetme sonrası birtakım programların (Wilson ve diğerleri, 2005; Visher ve diğerleri, 2006; Mitchell ve diğerleri, 2012; Petrosino ve diğerleri, 2003) ya da sadece seçenek yaptırımların kendi aralarındaki etkinliğine odaklanan araştırmalar (Garrido \& Quintro, 2007; Strang ve diğerleri, 2013) bu çalışmaya dahil edilmemiştir.

(3) Yapılan müdahale, homojen yapıda olmalıdır; bir başka ifadeyle, kontrol ve deney grubuna, ya hürriyeti bağlayıcı ya da seçenek yaptırımdan biri uygulanmalıdır. Dolayısıly herhangi bir sistematik derlemenin bu çalışmaya dâhil olabilmesi için müdahale yöntemleri birbirine karıştırılarak uygulanmamış olmalıdır. Örneğin, şirket suçlarının önlenmesinde cezalandırıcı olan ve olmayan yaptırım türlerinin karşılaştırıldığı bir çalışma, cezalandırıcı yaptırımlar arasına hem kişiyi özgürlüğünden mahrum bırakan hem de bırakmayan yaptırımları dâhil ettiği için kapsam dışında tutulmuştur (Simpson ve diğerleri, 2014). Ayrıca Smith ve arkadaşlarının çalışması da (Smith ve diğerleri, 2002) bu konuda yapılmış olan ilk sistematik derleme çalışmasının güncellenmiş hali olmasına rağmen çalışmada seçenek yaptırımlar boot camp ve scared straight gibi hapis cezasının infazına ilişkin programları da içerdiği için dâhil edilmemiştir.

(4) Bütün çalışmalarda, hapis ve seçenek yaptırım (müdahale) sonrası ölçüm hükümlünün mükerrer suçluluğuna ilişkin olmalıdır. Bazı sistematik derlemeler müdahalenin mükerrer suçluluk üzerindeki etkisini değil; örneğin sadece infaz maliyetleri (McDougall ve diğerleri, 2008) veya sadece hükümlünün sosyal hayata entegrasyonunu (Murray ve diğerleri, 2009) değerlendirdiğinden dâhil edilmemiştir. Fakat bir araştırma içerisinde birden fazla soruya 
cevap aranıyor da olabilir. Bu durumda mükerrer suç oranına olan etki ayrılabiliyor ise çalışmamıza dâhil edilmişsir. Örneğin, Jonson'ın (2010) çalışmasında, hapis cezası ile seçenek yaptırımların mükerrer suçluluk üzerindeki etkisinin yanı sıra, hapsetme süresinin ve infaz şartlarının da tekrar eden suçluluk üzerindeki etkisi araştırılmıştır. Ancak çalışmada, meta-analiz sonuçları her bir değişken için ayrı ayrı sunulduğundan, hapis ve seçenek yaptırımın tekrar eden suçluluk üzerindeki etkisine ilişkin kısmı sistematik derlememize dâhil edilmiştir. Ayrıca tekrar suçluluk ölçümünde sadece yeniden hapsedilme oranı değil; yeni bir mahkûmiyet, denetimli serbestlik veya koşullu salıverilme şartlarının ihlali de dikkate alınmıştır.

(5) Dâhil edilen çalışmaların sonuçlarl meta-analitik yöntemle incelenmiş olmalıdır. Hapis ve seçenek yaptırımın mükerrer suçluluk üzerindeki etkinliğini öyküsel olarak inceleyen ve meta-analitik yöntem kullanmayan niteliksel sistematik derlemeler bu çalışmaya dâhil edilememiştir.

$\mathrm{Bu}$ çalışmada yer verilen meta-analiz çalışmalarına şöyle bir yöntem izlenerek ulaşılmıştır. Illk olarak, 08.03.2016 tarihi itibari ile Campbell Collaboration'ın sistematik derlemeler kütüphanesinde (The Campbell Collaboration Library of Systematic Reviews) "Suç ve Adalet" (Crime and Justice) grubu içerisindeki 20032016 yıllarında yayınlanan bütün derleme çalışmaları, başlık ve anahtar kelimeleri tek tek "prison v. alternative sanction", "custodial v. non- cucstodial", "formal v. immediate sanction" anahtar kelimeleri kullanılarak taranmıştır. Bu arama neticesinde otuz sekiz çalışma bulunmuştur. Campbell İşbirliği, sosyal, davranışsal ve eğitimle alakalı alanlarda sistematik derleme çalışmalarını destekleyen ve kâr amacı gütmeyen bir kuruluş olup; Suç ve Adalet Grubu, bilhassa ceza adalet sistemi içerisinde failler üzerinde gerçekleştirilen müdahale programlarının etkinliğini değerlendiren yüksek kalitede sistematik derleme çalışmalarını desteklemektedir (Farrington \& Petrosino, 2001; Topçuoğlu, 2016: 93).

İkinci aşamada, Google Akademik’te "prison sentence", "alternative sanction", "custodial", "non-custodial", "systematic review", "recidivism" anahtar kelimeleri 
iki farklı kombinasyon yapılarak toplamda 2000 kaynak taranmıştır².

Son aşamada ise, ilk iki aşamada elde edilen 2038 çalışma içerisinde başta belirlenen seçme kriterlerine uygun bulunan sistematik derleme çalışmalarının kaynakçaları taranmıştır. Aynı sistematik derlemenin birden fazla versiyonu bulunması durumunda en güncel olan sistematik derlemeye yer verilmiştir. Sonuç olarak, başta belirlenen kriterlere uygun toplamda $\ddot{u}$ meta-analiz çalışması tespit edilmiş̧ir.

\subsection{Bulgular}

Yapılan sistematik arama sonucunda hapis cezası ile seçenek yaptırımların mükerrer suçluluğun önlenmesi üzerindeki etkisini inceleyen $\ddot{u}$ ç meta-analiz çalışması tespit edilmiştir (Nagin ve diğerleri, 2009; Jonson, 2010; Villettaz ve diğerleri, 2015). $\mathrm{Bu}$ çalışmalarda ele alınan değerlendirme çalışmalarının sayısı ve tasarım özellikleri, kapsanan yıllar, ülke ve dil kapsamı, yayınlanmış olma şartı aranıp aranmadığı gibi birtakım özellikleri Tablo 1'de gösterilmiştir. Genel olarak bu üç çalışma, 1960-2013 yılları arasında gerçekleştirilmiş etkinlik çalışmalarını içermektedir. Her üç metaanaliz çalışması da içerdiği etkinlik çalışmaları bakımından birbirinden bağımsız değildir, kimi durumlarda dâhil edilen çalışmalar birbiri ile örtüşmektedir.

Nagin, Cullen ve Jonson (2009) tarafından gerçekleştirilen meta-analiz çalışmasında, ülke ve dil sınırlaması olmadan ve yayınlanmış olma şartı aranmadan hapis cezası ve seçenek yaptırımların mükerrer suçluluk üzerindeki etkisi sistematik olarak araştırılmıştır. Esasında çalışmanın iki temel sorusu bulunmaktadır. İlki, hapis cezası ile seçenek yaptırımların tekrar suçluluk üzerindeki etkisi; ikincisi ise hapis cezasının süresinin (uzunluğunun-kısalığının) mükerrer suçluluk üzerindeki etkisidir. Araştırma sonuçları, her iki soru için de ayrı ayrı sunulduğundan Nagin ve arkadaşlarının meta-analiz çalışmasına bu sistematik derlemeye dâhil edilebilmiştir. Çalışmada ele alınan ve hapis cezası ile seçenek yaptırımların tekrar eden suçluluk üzerindeki etkisini değerlendiren bütün etkinlik çalışmaları, kullanılan metod açısından incelenmiş ve dört ayrı grupta değerlendirilmiştir. İlk aşamada, birbirine olabildiğince benzer özelliklerdeki hükümlülerin deney ve kontrol grubuna rastlantısal olarak yerleştirildiği dört deneysel (Barton ve Butts, 1990; Bergman, 1976; Killias ve diğerleri, 2000; Schneider, 1986) ve bir yarı deneysel (Van der Werff, 1979) çalışma; ikinci aşamada, gözlemsel veriye dayanan on bir eşleştirme çalışması (Apel \& Sweeten, 2008; Kraus, 1974, 1978, 1981; Loughran ve diğerleri, 2008; Muiluvuori,

2 Google Akademik’te yapılan her aramada sadece ilk 1000 kaynak gösterilmektedir. 
2001; Petersilia ve diğerleri, 1986; Savolainen ve diğerleri,2002; Smith \& Akers, 1993; Weisburd ve diğerleri, 2001) değerlendirilmiştir. Üçüncü aşamada ise gözlemsel veriye dayanan otuz bir regresyon çalışması ve son olarak dördüncü aşamada diğer metotları kullanan ve azınlıkta kalan yedi çalışma meta-analitik yöntemle değerlendirilmiştir.

Nagin ve diğerlerinin (2009) çalışmasında elde edilen bulgular, seçenek yaptırımlarla karşılaştırıldığında hürriyeti bağlayıcı cezaların suçun önlenmesinde hiç veya önemsiz etkisinin olduğuna dair kanıtlar ortaya koymaktadır. Hürriyeti bağlayıcı cezaların önleyici etkisi istatistiksel olarak anlamlı değildir. İlk aşamada

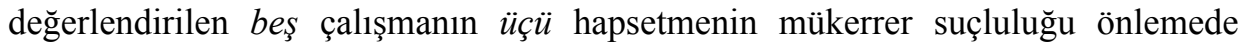
sadece bir puan etkili olduğunu gösterirken; yalnızca bir çalışma (Barton ve Butts, 1990) istatistiksel olarak anlamlı bir etkisi olduğunu göstermektedir. Fakat bu etkinin, hapsetmenin olanaksızlaştırıcı bir başka ifadeyle kısıtlayıcı (incapacitation) etkisinden kaynaklandığı da belirtilmelidir. İkinci aşamada değerlendirilen on bir çalışmanın sonuçları karma özellik göstermektedir. Hapis cezasının mükerrer suçluluğu önlemede etkili olduğuna ilişkin istatiksel olarak anlamlı bulguların tespit edildiği çalışmalar olduğu gibi (Nieuwbeerta ve diğerleri); aksi yönde çalışmalar (Weisburd ve diğerleri, 1995; Smith ve Akers, 1993) da vardır. Üçüncü aşamada değerlendirilen otuz bir çalışmanın yirmi ikisinde hapis cezasının tekrar eden suçluluktaki etkisi pozitif, yedi çalışmada negatif ve $i k i$ çalışmada ise eşit etki tespit edilmiştir. Hürriyeti bağlayıcı cezanın mükerrer suçluluktaki etkisinin pozitif olduğu yirmi iki çalışmanın sadece on yedisi istatistiksel olarak anlamlı iken; tekrar suçluluk üzerindeki etkinin negatif olduğu sekiz çalışmanın yedisi istatistiksel olarak anlamlidir.

Jonson (2010) ise doktora tezi olarak hazırladığı çalışmasında, ülke ve dil sınırlaması olmadan ve yayınlanmış olma şartı aranmadan hapis ve seçenek yaptırımların mükerrer suçluluğun önlenmesindeki etkisini değerlendiren etkinlik çalışmalarını sistematik olarak araştırmıştır. Aslında bu sistematik derlemenin üç temel sorusu bulunmaktadır. İlki, seçenek yaptırımların hapsetmeye nazaran mükerrer suçluluk üzerindeki etkisi nedir? İkincisi, hapsetme süresinin serbest bırakılan mahkumlar üzerindeki etkisi nedir? Üçüncüsü ise, ağır infaz şartları ile daha hafif infaz şartlarının (hapis) mükerrer suçluluk üzerindeki etkisi nedir? Bu üç temel sorudan en azından birini inceleyen ü̧̧ yüz bir çalışma tespit edilmiş; seksen beşi değerlendirme kriterlerine uygun bulunmuştur. Bu seksen beş çalışmanın, elli 
yedisi hapis cezası ve seçenek yaptırımların mükerrer suçluluk üzerindeki etkisini değerlendirmektedir ve 177 etki büyüklü̆̆̈̈ oluşturmaktadır. Yirmi yedi etkinlik çalışması ise hapsetme süresini değerlendirmektedir ve 50 etki büyüklüğüne sahiptir. On bir çalışma ise infaz şartlarını değerlendirmektedir ve etki büyüklüğü 15 'tir. Etki büyüklüğü, etkinlik çalışmasında ele alınan söz konusu programın belirlenen sonuç değişkeni üzerindeki etkisini ifade etmektedir (Topçuoğlu, 2016: 93). Meta-analiz çalışmalarında kullanılan etki büyüklüğü ölçütleri araştırmacının tercihine göre farklılık gösterebilmekle beraber, genel olarak, her bir ölçüt, arzu edildiğinde istatistiksel olarak bir diğerine çevrilebilmektedir (Topçuoğlu, 2016: 93).

Bizim sistematik derlememiz bakımından, çalışmanın birinci sorusuna ilişkin sonuçlar önem arz ettiğinden dolayı sonuçlar o minvalde sunulacaktır. Jonson'ın, araştırmasının ilk sorusuna yanıt ararken sistematik derlemesine dahil ettiği elli yedi etkinlik çalışmasının neredeyse yarısı (\%49.2) 2000-2010 yılları arasında yayınlanmış araştırmalardan oluşmaktadır. Üçte biri (\%31.1) 1990'larda, kalan azınlı̆̆ (\%19.8) ise 1960 ila 1989 yılları arasında yayınlanmış çalışmalardır. Araştırmaların büyük çoğunluğu (\%51.4) Amerika'da yapılmıştır. Amerika'yı takiben İngiltere (\%9.6), Avustralya (\%5.6), Kanada (\%2.8) ve diğer (\%30.5) ülkeler gelmektedir. Etkinlik çalışmaları, mükerrer suçluluğun tespitinde tutuklama (\%15), mahkumiyet (\%28), yeniden hapsedilme (\%52), denetimli serbestliğin veya koşullu salıverilmenin ihlalini (\%1.1) esas almaktadır.

Hapis cezası ve seçenek yaptırımların mükerrer suçluluk üzerindeki etkisini değerlendiren elli yedi çalışmayı (k=177 etki büyüklüğü) inceleyen Jonson, bu iki yaptırım türü ile tekrar eden suçluluk arasında ortalama etki büyüklüğünü $\mathrm{r}=-11$ ve ăğrlıklı ortalama etki büyüklüğünü $\mathrm{Z}+=-1440$ olarak belirlemiştir. Daha kesin ifadelerle belirtmek gerekirse, hapis cezasına mahkum olanların mükerrer suçluluk oran $\% 55.5$ iken, seçenek yaptırıma tabi olanlarda bu oran \%44.5'tir. Bu hesap, ortalama etki büyüklüğü (r) ikiye bölünüp, 50 eklenip/çıkarılarak bulunmuştur $(50+/-11 / 2=44.5$ ve 55.5 sirasiyla). Bununla birlikte, $Q$ istatistiği ile hesaplandığında hapis ve seçenek yaptırımların karşılaştırılması istatistiksel olarak anlamlıdır. Sonuçlar üç standart ortalama sapmadan daha büyüktür ve 62 etki büyüklügünden uzaklaşılmıştır. Hem ortalama etki büyüklüğü, hem de ağırlıklı ortalama etki büyüklüğü sönüktür. Ancak hâlâ ortalama etki büyüklüğü ve ağırlıklı ortalama etki büyüklüğü negatiftir ve seçenek yaptırımlar için tekrar eden suçluluğun 
azalmasına ilişkin istatistiksel olarak anlamlı sonuçlar bulunmaktadır. Jonson, yüksek kalitede etkinlik çalışmalarına odaklandığ 1 meta-analiz çalışması sonucunda, hapis cezasının seçenek yaptırıma oranla tekrar eden suçluluğu \% 5 artırdı ğını ortaya koymaktadır.

Villettaz, Gillieron ve Killias (2015) tarafından gerçekleştirilen meta-analiz çalışmasında ise ülke ve dil sınırlaması olmadan ve yayınlanmış olma şartı aranmadan 1961-2013 yılları arasında yazılmış hapis ve seçenek yaptırımların mükerrer suçluluk üzerindeki etkisini değerlendiren etkinlik çalışmaları sistematik olarak araştırılmaktadır. Bu sistematik derleme, aslında yazarların 2006 yılında yayınladıkları sistematik derlemenin güncellenmiş versiyonudur. İlk halinde $\ddot{u} c ̧$ binden fazla çalışmanın özetine bakılmış ve ü̧ yüzden fazlası da değerlendirme kriterlerine uyabilecek çalışmalar olarak incelenmiştir. Bu güncellenmiş hali için ise, 2003-2013 yılları arasında tamamlanmış veya yayınlanmış yaklaşık yüz yeni çalışma tespit edilmiş ve on iki tanesi değerlendirme kriterlerine uygun bulunmuştur.

Yazarlar sistematik derlemeye dâhil ettikleri on iki çalışmayı iki aşamalı olarak değerlendirmişlerdir. İlk aşamada, Raslantısal Kontrol Deneyi (randomized controlled trial) ve Doğal Deney (natural experiment) tasarımını kullanan dört (Van der Werrf, 1979; Barton, 1990; Schneider, 1986; Killias, 2010) çalışma değerlendirilmiştir. İkinci aşamada ise, Eğilim Skoru Eşleştirmesi (propensity score matching) tasarımını kullanan yarı-deneysel sekiz (Wermink ve diğerleri, 2010; Lulham ve diğerleri, 2009; Nieuwbeerta ve diğerleri, 2009; Loughran ve diğerleri, 2009; Nirel ve diğerleri, 1997; Apel ve diğerleri, 2010; Weisburd ve diğerleri, 1995; Bales \& Piquero, 2012 ) çalışmayı dâhil etmişlerdir.

Etkinlik çalışmalarının sonuçlarının geçerliliği açısından en güvenilir tasarım, müdahale öncesi ve sonrası ölçümler içeren, birbirine olabildiğince benzer özelliklere sahip deneklerin, deney ve kontrol grubuna rastlantısal olarak yerleştirildiği Rastlantısal Kontrol Deneyi (randomized controlled trial) dir. Her ne kadar rastlantısal kontrol deneyi kadar başarılı sonuçlara sahip olmasa da ona en yakın yöntem olarak, Eğilim Skoru Eşleştirmesini kullanan yarı-deneysel çalışmalar gösterilebilir. Bu tasarım, program uygulanmadan evvel iki grup arasında birtakım farklılıkların olabileceği ve bunun da sonucu etkileyeceği düşüncesine dayanmaktadır. Bu nedenle genellikle yaş, cinsiyet, ırk, önceki suç kaydı ve işlediği suç tipi olmak üzere beş farklı değişken eşleştirmede esas alınmaktadır. $\mathrm{Bu}$ yöntem, klasik eşleştirmeye nazaran daha avantajlıdır (Villettaz ve diğerleri, 2015: 47). 
Yazarlar, sistematik derlemelerinde öncelikle rastlantısal kontrol deneyi ve doğal deney tasarımını, ardından eğilim skoru eşleştirmesini kullanan çalışmalara yer vermişlerdir. Bunun dişında, Sherman'ın Metot Skor Ölçeği ${ }^{3}$ 'ne göre Seviye 3'e tekabül eden yarl-deneysel (quasi-experiment) çalışmaları değerlendirme dişı bırakmışlardır (ör. Albrecht, 1984; McIvor, 1990; Bartels, 2009). Bu da yazarların meta-analiz çalışmasını, sadece en güncel çalışma yapmakla kalmamış, aynı zamanda güvenilir sonuçların alınabileceği kaliteli bir araştırma da yapmıştır.

Meta-analizin ilk aşamasında değerlendirilen ve rastlantısal kontrol deneyi tasarımını kullanılan dört çalışmanın ikisinde belirsiz etki-etkisiz (null effect), birinde seçenek yaptırım lehinde ve doğal deney tasarımını kullanan, birinde ise trafik ve mal varlığına karşı suçlar bakımından hiçbir etki (none) olmadığı tespit edilmiştir. Metaanalizin ikinci aşamasında değerlendirilen ve eğilim skoru eşleştirmesini kullanan

3 Bütün değerlendirme çalışmalarının ortaya koyduğu bulguların aynı bilimsel güvenilirlikte olmadığ1 belirtilmelidir. Değerlendirme çalışmaları kullandıkları araştırma tasarımı ve sahip oldukları bilimsel geçerliliğe göre kendi aralarında derecelendirilmektedir. Bu derecelendirmede ABD'de geliştirilen “Maryland Bilimsel Metotlar Ölçeği” sıklıkla kullanılmaktadır. (Topçuoğlu, 2015(a): 3). Söz konusu ölçek, araştırmaları kullandıkları yönteme göre çeşitli puanlar vererek sıralamaktadır. Böylece bilimsel geçerliliği zayıf olan araştırmaların sonuçlarına dayanarak aslında işe yaramayan suç önleme veya iyileştirme programlarının devam ettirilip yaygınlaştırılması riskini azaltmaktadır (Topçuoğlu, 2015(a): 3).

Bilimsel Metot Skoru, deneysel, yarı deneysel ve deneysel olmayan şeklinde çeşitli araştırma deseni kullanan çalışmaları 1 ile 5 arasında değişen, bilimsel geçerliliğe olan tehditlerin en az olduğu çalışmanın 5 puan aldığı bir sisteme dayanmaktadır. Tersinden hareketle, bilimsel geçerliliğe olan tehditlerin en fazla olduğu çalışma 1 puan almaktadır. Seviye l'deki değerlendirme çalışmaları, gerçekleştirilen suç önleme veya iyileştirme programı ile üzerinde etki yaratılması beklenen sonuç değişkeninin aynı zaman diliminde ölçüldüğü kesitsel çalışmalardır. Seviye 2'deki değerlendirme çalışmaları, uygulanan program ile sonuç değişkeninin ölçümü arasında zaman sırasının var olduğu ve fakat uygulama öncesi-sonrasına ilişkin sonuç değişkeninde ölçüm olmasına rağmen karşılaştırıldığı bir kontrol grubunun bulunmadığ1 ya da söz konusu programa dâhil olan kişilerin kendileri ile karşılaştırmaya uygun olmayan bir kontrol grubu ile karşılaştırıldığı boylamsal çalışmalardır. Seviye 3'deki değerlendirme çalışmaları ise program öncesi ve sonrası ölçümlerin yapıldığı ve suç önleme veya iyileştirme programının uygulandığı grup ile karşılaştırılabilir bir kontrol grubunun bulunduğu boylamsal çalışmalardır. Seviye 4'deki değerlendirme çalışmaları, üçüncü seviyedeki çalışmaların aynısıdır; bununla beraber aralarındaki fark karşılaştırılan gruplar arasında program veya uygulama öncesinde var olan ve sonucu etkileyebilecek mevcut farklılıkların eşleştirme yoluyla ya da istatistiksel olarak kontrol edilmesi sonucunda birbirine daha benzer ya da denk olan karşılaştırma gruplarının birbiri ile karşılaştırılmış olmasıdır. Son olarak, Seviye 5'deki değerlendirme çalışmaları dördüncü seviyedeki çalışmaların aynısıdır; bunların aralarındaki tek fark ise karşılaştırılan gruplar arasında program veya uygulama öncesinde bulunan ve sonucu etkileyebilecek farklılıklar istatistiksel olarak değil, rastlantısal kontrollü deney yoluyla kontrol edilmektedir. (Topçuoğlu, 2015(a): 4-5).

Bu ölçeğe göre, bir programın sonuç değişkeni üzerinde etkili bir program sayılabilmesi için; değerlendirme çalışmasının sonuçları programın başarılı olduğunu göstermeli ve BMS'den 4 veya 5 puan almış olması gerekmektedir. Buna karşın, skoru 1 veya 2 olan çalışmalar, sonuçları ne olursa olsun bilimsel olarak güvenilir kabul edilmemektedir. Uygulamanın BMS'sinin 3 olması durumunda ise, programın umut verici ve işe yarayabilir olduğu kabul edilmektedir. Uygulanan politikaların süreç ve sonuç değerlendirilmesine iliş̧in bilimsel yeterlilikte çalışmaların nasıl yapılacağına ilişkin ayrıntılı bilgi için bkz. Topçuoğlu, “Türkiye'de Denetimli Serbestlik Hizmetlerinin Etkinliğinin Bilimsel Olarak Değerlendirilmesi”, Denetimli Serbestlik 10. Y11 Sempozyumu, 2015. 
yar1-deneysel sekiz çalışmanın yedisinde seçenek yaptırım lehinde, birinde ise kayda değer bir etki olmadığı tespit edilmiştir. Bununla birlikte, meta-analize dâhil edilmeyen yarı-deneysel çalışmaların büyük bir çoğunluğunda seçenek yaptırımlar hapsetmeye nazaran suçun önlenmesinde çok daha etkili olarak gösterilmektedir (ör. Muiluvuori, 2001; Petersilia ve diğerleri, 1986). Fakat araştırmaların kalitesi arttıkça iki yaptırım türü arasında aslında kayda değer bir fark olmadığı ortaya koyulmuştur.

Tespit edilen etkinlik çalışmaları üzerinden gerçekleştirilen meta-analiz sonuçlarına göre; hürriyeti bağlayıcı cezalar, tekrar eden suçluluğu önlemede istatistiksel olarak anlamlı bir etkiye sahip değildir. Bununla birlikte, seçenek yaptırımlar, mükerrer suçluluğun önlenmesinde etkilidir. Fakat bu etki, kayda değer bir büyüklükte değildir (İkinci çalışmada: 0.1; üçüncü çalışmada: ilk aşamada, 0.946 ortalama etki büyüklüğü; ikinci aşamada 0.693 ortalama etki büyüklüğü). Yine de hapis cezası ile mukayese edildiğinde, seçenek yaptırımlar görece az bir oranda da olsa mükerrer suçluluğu hapis cezasından daha fazla önleyebilmektedir.

\section{Sonuç ve Değerlendirme}

Hapis cezası, uzun yıllardır ceza adalet sisteminin bel kemiğidir. Bununla birlikte, hapis cezasının infazı ve sonuçları, devlete ciddi ekonomik külfetler yüklemektedir ve elde edilen sonuç kimseyi memnun da etmemektedir. Nitekim dünya genelinde artan hapishane nüfusu ve tekerrürün istikrarla artış göstermesi; hapsetmenin, cezanın amacını gerçekleştirmeye en uygun yaptırım türü olup olmadığının sorgulanmasını sağlamıştır. Bugüne kadar yapılan ampirik çalışma bulguları da hapsetmenin tek başına mükerrer suçluluğu azaltıcı yönde özel bir caydırıcı etkisi olmadığını, hatta tekrar eden suçluluğu artırabileceğini göstermektedir (Smith, Goggin ve Gendreau, 2002; Nagin, 2012; Topçuoğlu, 2016: 101). Kısa süreli hapis cezası da ceza adalet politikası tartışmalarının odağında bulunmaktadır. Bunun nedeni de kısa süreli hapis cezasının hem hapsetmenin genel sakıncalarını hem de kendine özgü birtakım sakıncaları barındırmasıdır. Bu nedenle hapis cezasının sakıncalarını gidermeye yönelik olarak, hapsetmenin sınırlandırılması ve seçenek yaptırımlara hükmedilmesi eğilimi güç kazanmaktadır. Fakat bu eğilimin de etkinliğinin (işe yararlığının) değerlendirilmesi gerekmektedir.

$\mathrm{Bu}$ çalışma, metot bölümünde ortaya koyulan kriterler 1şığında bugüne kadar yapılmış meta-analiz çalışmalarını inceleyerek, hapis cezası ve seçenek yaptırımların suçun önlenmesi üzerindeki etkisine ilişkin bulguları özetlemeyi ve Türkiye'de ceza 
adalet sistemi için politika üretenlere bilimsel kanıta dayalı önerilerde bulunmayı amaçlamaktadır. Çalışmanın başında belirtilen kriterler takip edilerek yapılan sistematik arama sonucunda $\ddot{u} ̧ ̧$ meta-analiz çalışması tespit edilmiştir (Nagin ve diğerleri, 2009; Jonson, 2010; Villettaz ve diğerleri, 2015).

\section{Tablo 1: Sistematik Derlemeye Dâhil Olan Meta-Analiz Çalışmalarının Belli Başlı Özellikleri}

\begin{tabular}{|c|c|c|c|c|c|c|}
\hline $\begin{array}{c}\text { Yll } \\
\text { (Yazar) }\end{array}$ & $\begin{array}{c}\text { Dâhil Edilen } \\
\text { Etkinlik } \\
\text { Değerlendirme } \\
\text { sayısı }\end{array}$ & $\begin{array}{c}\text { Değerlendirilen } \\
\text { programlar }\end{array}$ & $\begin{array}{c}\text { Değerlendirme } \\
\text { çalışmalarının } \\
\text { tasarım } \\
\text { özelliği }\end{array}$ & $\begin{array}{c}\text { Kapsanan } \\
\text { yillar }\end{array}$ & $\begin{array}{c}\text { Ülke ve yazım } \\
\text { dili şartı }\end{array}$ & $\begin{array}{c}\text { Yayımlanma } \\
\text { şartı }\end{array}$ \\
\hline $\begin{array}{l}2009 \\
\text { (Nagin, } \\
\text { Cullen ve } \\
\text { Jonson) }\end{array}$ & $\mathrm{n}=66$ & $\begin{array}{l}\text { Hürriyeti } \\
\text { bağlayıcı cezalar } \\
\text { ve seçenek } \\
\text { yaptırımlar } \\
(\mathrm{n}=46) \\
\text { Hürriyeti } \\
\text { bağlayıcı } \\
\text { cezanın süresi } \\
(\mathrm{n}=20)\end{array}$ & $\begin{array}{l}\text { Deneysel ve } \\
\text { yar1-deneysel }\end{array}$ & Belirtilmemiş & Sinırlama yok & Yok \\
\hline $\begin{array}{l}2010 \\
\text { (Jonson) }\end{array}$ & $\mathrm{n}=85$ & $\begin{array}{l}\text { Hürriyeti } \\
\text { bağlayıcı cezalar } \\
\text { ve seçenek } \\
\text { yaptırımlar } \\
(\mathrm{n}=57) \\
\text { Hürriyeti } \\
\text { bağlayıcı } \\
\text { cezanın süresi } \\
\text { (n=27) } \\
\text { İnfaz şartlarının } \\
\text { ağırlığı-hafifliği } \\
\text { (n=11) }\end{array}$ & $\begin{array}{l}\text { Deneysel ve } \\
\text { yar1-deneysel }\end{array}$ & 1960-1989 & $\begin{array}{l}\text { Sinırlama yok } \\
\text { (Amerika \%51, } \\
\text { İngiltere } \% 20 \text {, } \\
\text { Avustralya } \% 6 \text {, } \\
\text { Kanada } \% 3 \text { ve } \\
\text { diğer } \% 30 \text { ) }\end{array}$ & Yok \\
\hline $\begin{array}{l}2015 \\
\text { (Villettaz, } \\
\text { Gillieron } \\
\text { ve Killias) }\end{array}$ & $\mathrm{n}=12$ & $\begin{array}{l}\text { Hürriyeti } \\
\text { bağlayıcı cezalar } \\
\text { ve seçenek } \\
\text { yaptırımlar ( } \mathrm{n}= \\
\text { 12) }\end{array}$ & $\begin{array}{l}\text { Deneysel ve } \\
\text { yarı-deneysel } \\
\text { (Rastlantısal } \\
\text { Kontrol } \\
\text { Deneyi, Eğilim } \\
\text { Skoru } \\
\text { Eşleştirmesi) }\end{array}$ & $1961-2013$ & Sinırlama yok & Yok \\
\hline
\end{tabular}

$\mathrm{Bu}$ üç meta-analiz çalışmasından elde edilen bulgulara dayanılarak birtakım sonuçlar çıkarmak mümkündür. İlk olarak, hapis cezası ve seçenek yaptırımların mükerrer suçluluk üzerindeki etkisini değerlendiren sistematik derleme sayısının oldukça sınırlı olduğu görülmektedir. Fakat bu alanda yapılan etkinlik sayısı ise fazladır. Araştırmacıların, sistematik derleme yapmaktan ziyade bir veya daha fazla seçenek yaptırım türü ile hapis cezasını karşılaştırmayı tercih ettikleri görülmektedir. 
İkinci olarak, bu çalışma, seçenek yaptırımların hapis cezalarına nazaran tekrar eden suçluluğun önlenmesinde daha etkili olduğuna ilişkin bulgular ortaya koymaktadır. Hapis cezası ise mükerrer suçluluğun önlenmesinde istatistiksel olarak anlamlı bir etkiye sahip olamadığı gibi (Nagin ve diğerleri, 2009); bilakis tekrar eden suçluluğun artmasına da neden olabilmektedir (Jonson, 2010). Söz konusu bulgular, en etkili suç önleme yöntemi olarak hapsetmeyi öngören caydırıcılık teorisinin varsayımları ile çelişmektedir. Fakat kontrol grubunda bulunan ve hapis cezası alan mahkûmların belli bir risk grubundaki ve belli suçları işleyen failler oldukları da gözden kaçırılmamalıdır. Zira deney grubunun oluşturulabilmesi için, seçenek yaptırıma çevrilebilir nitelikteki hapis cezasını gerektiren suçların işlenmiş olması gerekir. Hukuk sistemlerinde, genellikle 6 ay veya 1 yıl süreli hapis cezaları seçenek yaptırıma çevrilebilmektedir. Ayrıca sınırlı sayıda ülkede (İngiltere, İspanya, Hollanda, Belçika gibi) ise seçenek yaptırımlar müstakil bir ceza olarak uygulanmaktadır. Dolayısıyla hakkında kısa süreli hapis cezasına veya seçenek yaptırıma hükmedilebilecek, belli özelliklerdeki suçları işleyen ve genellikle düşük risk grubundaki failler için sonuçların geçerli olduğu söylenebilirken; uzun süreli hapis cezasına mahkûm olanlar için aynı şeyi söylemek mümkün gözükmemektedir.

Her ne kadar Villettaz ve diğerlerinin çalışmasında, araştırmaların metot açısından kalitesi arttıkça, iki yaptırım türü arasında aslında kayda değer bir fark olmadığı ortaya koyulsa da araştırma bulguları, her halükarda seçenek yaptırımların -görece az bir oranda da olsa- kısa süreli hapis cezasına nazaran suçun önlenmesinde daha etkili olduğunu göstermektedir. Belki de araştırma bulgularını şöyle özetlemek gerekir: Hapis cezası, mükerrer suçluluğu seçenek yaptırımlardan daha fazla önleyemiyor. Kriminologların diliyle söyleyecek olursak, günümüzde artık hapsetmenin özel caydırıcı etkisi (the specific deterrent effect) yeterli değildir. Kaldı ki seçenek yaptırımların etki oranı sıfir bile olsa, hapishanenin inşa ve idare masrafları ile hapsetmenin diğer negatif yan etkileri de düşünüldüğünde, neden hâlâ bilhassa klsa süreli hapis cezasından vazgeçilemediğini anlamak güçleşecektir.

$\mathrm{Bu}$ sorunun cevabı, hapsetmenin olanaksızlaştırıcı (incapacitation) etkisinde bulunabilir. Nitekim hapis cezasına mahkûm olan kişinin hareket özgürlüğü kısıtlanarak suç işlemesi önlenebilmektedir. Fakat bu etki, geçici bir süre için geçerli olacaktır. Kaldı ki, hapishanelerin adeta bir suç okulu gibi yeni suç ve suçlular ürettiği, mahkûmların cezaevinde bilhassa uyuşturucu veya cinsel suç gibi birtakım 
suçların hem faili hem mağduru olabildiği de düşünülürse, olanaksızlaştırıcı veya kısıtlayıcı etkinin ne derece etkili olduğu da şüphelidir.

Hapis cezasından vazgeçilememesinde, hapsetmenin iyileştirici veya olanaksızlaştırıcı etkisinden ziyade; kamuoyunda etkili bir ceza olarak görülmesi, topluma güven vermesi ve adalet (burada çoğunlukla intikam anlamında) duygusunu tatmin etmesi başat faktörler olarak gösterilebilir. Yaptırımın türü, cezanın amacıyla ilişkilidir ve kusurun ağırlığıyla orantılıdır. Her ne kadar son yıllarda, hapis cezasının infazında, cezaevi dışındaki infaz yöntemleri ve seçenek yaptırımlar ceza adalet politikası tartışmalarının odağında bulunsa da toplumsal yaşamın önemli hukuksal değerlerini ihlal eden suçlar, tekerrür ve tehlikeli şiddet suçluluğu bakımından hapis cezası varlığını sürdürecektir (Abanoz, 2016: 58). Fakat hafif haksızlıkların cezalandırılmasında, kısa süreli hapis cezasından vazgeçilerek; failin, mağdurun ve işlenen suçun durumuna uygun olan seçenek yaptırımın müstakil olarak uygulanması üzerine düşünülmelidir.

Üçüncü olarak, bu çalışmada ortaya koyulan ve seçenek yaptırımların tekrar eden suçluluğun önlenmesinde etkili olduğuna ilişkin bulgular, bütün seçenek yaptırımlara genellenebilir mi? Tersinden hareketle, bu bulgulardan yola çıkarak hangi seçenek yaptırım türünün daha etkili olduğuna ilişkin bir sonuç çıkarabilmek mümkün müdür? Seçenek yaptırımların hapsetmeye nazaran daha etkili olduğuna ilişkin bulgular, bütün seçenek yaptırımlar için geçerli olmadığ 1 gibi, seçenek yaptırım türlerinden birini ayırarak diğerlerinden daha etkili olduğunu söyleyebilmek de mümkün gözükmemektedir. Dolayısıyla, başta sorduğumuz iki sorunun cevabı da olumsuzdur. $\mathrm{Bu}$ durum, dünya genelinde yapılan etkinlik çalışmalarındaki bir eksikliktir. Bununla birlikte, etkinlik çalışmalarında bilhassa iki seçenek yaptırım türünün ön plana çıktığ1 görülmektedir. İlki, denetimli serbestlik ${ }^{4}$ (Bergman, 1976; MacKenzie ve diğerleri, 1993; Bontrager ve diğerleri, 2013); ikincisi ise, kamuya yararlı bir işte çalıştırılmadır (Killias ve diğerleri, 2000; Wermink ve diğerleri, 2010; Muiluvuori, 2001). Fakat denetimli serbestlik ve kamuya yararlı bir işte çalıştırılmayı konu alan araştırmaların öne çıkması, bunların diğer seçenek yaptırımlardan daha etkin oldukları anlamına gelmemektedir. Zira etkinlik çalışmalarında, seçenek yaptırım türü ile hürriyeti

4 TCK'da denetimli serbestlik bir seçenek yaptırım türü olarak düzenlenmemiş olmasına rağmen, hapis cezası ile seçenek yaptırımların suçun önlenmesi üzerindeki etkisini değerlendiren etkinlik çalışmalarında denetimli serbestliğin hapis cezası ile karşılaştırıldığı görülmektedir. Nitekim çalışmalarda belirleyici olan yaptırım türü değil suç teşkil eden haksızlığa karşı verilen tepkinin hürriyeti bağlayıcı olup olmadığıdır. Dolayısıyla burada yaptırım kavramı kullanılsa da kastedilen suç teşkil eden haksızlığa karşı ceza adaletinin vermiş olduğu hürriyeti bağlayıcı olmayan tepkileridir. 
bağlayıcı cezayı mukayese edilmektedir ve tek tek seçenek yaptırım türlerini kendi aralarında karşılaştırılmamaktadır. Dolayısıyla denetimli serbestlik ve kamuya yararlı bir işte çalıştırılmayı değerlendiren araştırmaların ön plana çıkıyor oluşu, seçim yanlılı̆̆ından kaynaklanıyor olabileceği gibi yayın yanlılı̆̆ından da kaynaklanıyor olabilir. Bununla birlikte, her iki seçenek yaptırımın etkinliğine ilişkin araştırma sayısındaki yoğunluk, elbette anlamsız da olamaz.

Dördüncü olarak, söz konusu bulguların Türkiye için yol gösterici olup olamayacağı önemli bir meseledir. Öncelikle, Türkiye'de hapis cezası ve seçenek yaptırımların etkinliğini değerlendiren herhangi bir meta-analiz çalışmasının bulunmadığı belirtilmelidir ${ }^{5}$. Aslında bu konuda yapılmış herhangi bir etkinlik çalışması olduğunu söylemek de mümkün gözükmemektedir. Bazı çalışmalar (Kızmaz, 2007) ampirik dahi olmadığı için; bazı çalışmalar ise kontrol grubu olmayan yarı-deneysel çalışma (Ada \& Peker, 2012) olduklarından inceleme dışında bırakılmıştır. Bununla beraber, bir çalışma içerisinde (Karakaş-Doğan, 2012) hapis cezasının ve infaz koşullarının tekrar eden suçluluk açısından caydırıcı olup olmadığının değerlendirildiği tespit edilmiştir. Fakat çalışmada mahkûmlara yapılan anket çalışması verileri betimsel olarak sunulduğu için söz konusu çalışmaya da yer verilmemiştir. Bu konuda Türkiye'de ampirik bir araştırma yapılmamış olmasının birden fazla sebebi olabilir. İlki, bu konuda nitelikli bir bilimsel araştırma yapabilmenin kendi içinde barındırdığı zorluklar olabilir. Fakat asıl sebebi, Türkiye'de suçun tekerrürü ile ilgili güvenilir bir veriye ulaşabilmenin mümkün olmamasıdır'. Sonuç

5 Türkiye'de hapis cezası ve seçenek yaptırımların suçun önlenmesi üzerindeki etkisini değerlendiren araştırmalara ulaşabilmek için; sırasıyla Ulakbim, YÖK ve Google Akademik üzerinden, "alternatif yaptırım", "hapis cezası", "seçenek yaptırımların etkinliğì", "suçun önlenmesi” anahtar kelimeleriyle arama yapılmıştır.

6 Türkiye'de suçun ölçümü ağırlıklı olarak resmi kaynaklara dayanmaktadır. Bu resmi kaynaklar içerisinde de ceza infaz kurumu istatistiklerinin ön plana çıktığı söylenebilir. Bununla birlikte Polis istatistikleri Emniyet Genel Müdürlüğü (EGM) tarafından toplanmaktadır. Bu veriler, 2003 yılına kadar EGM'nin internet sayfası üzerinden yayınlanmış; fakat bu tarihten sonra söz konusu uygulamanın terk edildiği görülmüsstür (Topçuoğlu, 2015 (a): 170). Ayrıca polis istatistiklerinde yer alan suçlar sadece kentsel alanlara ilişkindir. Kırsal alanlarda meydana gelen olaylar ise Jandarma Genel Komutanlığı'nın sorumluluğundadır. Bu veriler de düzenli olarak Türkiye İstatistik Kurumuna (TÜIK) verilmekle beraber yayınlanmamaktadır. TÜİK tarafından yayınlanan Türkiye'deki ceza infaz kurumlarına ilişkin istatistikler, yıl içinde ceza infaz kurumlarına giren ve bu kurumlardan çıkan hükümlüler hakkında oldukça sınırlı ve betimleyici veriler sunmakta; bu veriler de mükerrer suçluluğu ölçmeye imkân vermemektedir (Topçuoğlu, 2015(a): 180). Kaldı ki, Türkiye'de resmi makamlar tarafindan kaydedilen tüm suç verilerine ulaşılsa dahi bu gerçek suç oranını görebilmek için yeterli olmayabilir. Bir de polise bildirilmeyen veya bildirilmesine rağmen faili bulunamayan veya sanık hakkında mahkûmiyet kararı verilemeyen suçlar olabilir. Bu noktada karanlık sayıları aydınlatmak amaciyla kullanılan "kişisel suç bildirim anketleri" nin henüz Türkiye'de ulusal düzeyde gerçekleştirilmediği tespit edilmektedir (Topçuoğlu, 2015(a): 173). Dolayısıyla Türkiye'de suçun tekerrürü ile ilgili güvenilir bir veriye ulaşabilmenin mümkün olmadığı söylenebilir. 
olarak, sadece mükerrer suçluluğu azaltıcı politikalar değil; Türkiye'de ceza adalet sistemi içerisinde uygulanan veya uygulanacak politikalar, bugüne kadar maalesef değerlendirilmemiştir. Bu durumun bir başka nedeni de mevcut veya uygulanacak herhangi bir ceza adalet politikasının etkinliğinin değerlendirilmesinin ne derece önemli olduğu Türkiye'de yeterince anlaşılamamıştır (Topçuoğlu, 2015 (a): 13). Oysa bilimsel kanıtlara dayalı olarak geliştirilen ve sistem içerisinde bu doğrultuda yapılan değişikliklerle uygulanan politikalar, hem daha fazla başarı şansına sahip olacak, hem de kamu kaynaklarının daha verimli kullanılmasını sağlayacaktır (Topçuoğlu, 2015(b): 167). Bununla birlikte, ceza adalet politikalarının vatandaşlar üzerinde uygulandığı ve çok ciddi sonuçlar doğurabileceği de dikkate alınacak olursa söz konusu politikaların bilimsel verilere dayalı olmasının ehemmiyeti anlaşılacaktır.

Sonuç olarak, bu çalışmada ortaya koyulan bulgular, her ne kadar yabancı menşeili olsa da Türkiye'deki ceza adalet politikaları için önem arz etmektedir. Fakat birebir benzer sonuçların alınacağını söylemek elbette mümkün değildir. $\mathrm{Bu}$ nedenle Türkiye'de de mevcut uygulamaların etkinlikleri (işe yararlılıkları) metot açısından yüksek kalitede bilimsel araştırmalarla değerlendirilmelidir.

Bununla beraber, bu çalışmanın da bazı sınırlılıkları bulunmaktadır. İlk olarak, bu çalışma hapis cezası ile seçenek yaptırımların mükerrer suçluluğun önlenmesi üzerindeki etkisini meta-analitik yöntemle değerlendiren sistematik derlemeleri özetlemeyi amaçlamaktadır. Dolayısıyla mevcut meta-analiz çalışmalarının bulgularıyla sınırlıdır. İkinci olarak, bu çalışma, hapis cezası ile seçenek yaptırımları, sadece mükerrer suçluluğu önlemesi bakımından değerlendirmektedir ve seçenek yaptırımların kısa süreli hapis cezasına nazaran tekrar eden suçluluğun önlenmesinde daha etkili olduğuna ilişkin bulgular ortaya koymaktadır. Nitekim çalışmada ortaya koyulan bulgular, dünya genelinde hapis cezasının sınırlandırılması ve seçenek yaptırımların geliştirilmesi eğilimini destekleyici niteliktedir. Fakat bu da başka bir ezbere -seçenek yaptırımların her halükarda daha avantajlı olduğu yönünde- sebep olabilir. Oysa iki yaptırım türü arasında sadece suçun önlenmesi bakımından değil; infaz masrafları, rehabilitasyon ve hükümlünün toplumsal hayata uyumu gibi birden fazla boyutta karşışş̦ırma yapılması gereklidir. Hapis cezasının devlete ciddi ekonomik külfetler getirdiği bilinmekle beraber; seçenek yaptırım türlerinin infazının da birtakım masrafları gerektireceği gözden kaçırılmamalıdır. Bununla birlikte, bu çalışmada değerlendirilen meta-analiz çalışmaları her ne kadar seçenek yaptırımların hapsetmeye nazaran daha etkili olduğuna ilişkin bulgular ortaya koysa da infaz 
koşullarının da ayrıca incelenmesi gerekir. Nitekim hapis cezasının infaz koşulları, etkililiğini belirleyen önemli faktörlerden biridir (ör: Mears ve diğerleri, 2014). Son olarak, söz konusu bulguların, bilhassa kısa süreli hapis cezası için geçerli olduğu unutulmamalı ve bu iki yaptırım türü arasında çok daha kapsamlı bir araştırma yapılarak, uygulama süreci ve sonucunu hedef alan, yukarıda zikredilen noktalar da nazara alınarak birden fazla boyutta karşılaştırma yapılması gerekmektedir. Ancak o zaman, hangi yaptırım türünden daha iyi sonuçlar alınabildiği ve daha avantajlı olduğu tespit edilebilecektir.

\section{Kaynakça}

ABANOZ, Buket, “Ceza İnfaz Kurumları'nda Özelleştirmenin Çok Boyutlu Değerlendirilmesi ve Türkiye'de Uygulanabilirliği”, V. Türkiye Lisansüstü Çalışmalar Kongresi, I. Kitap, 2016, s. 41-62. Bkz. http:// www.tlck.org.tr/wp-content/uploads/2016/10/TLCK.5.1.B003.pdf.

ADA, Şükrü, PEKER, Adem, “Tedavi ve Denetimli Serbestlik Tedbiri Uygulamasının Etkinliğinin İncelenmesi (Sakarya İli Örneği)”, AÜSBED, 2012, 16 (1), 425-438.

AKERS, Ronald L., SELLERS, Christine S., Criminological Theories: Introduction, Evaluation, and Application, New York, Oxford, Oxford University Press, 5. Edition, 2009.

ALBRECHT, H. J., "Recidivism after fines, suspended sentences and imprisonment", International Journal of Comparative and Applied Criminal Justice, 1984, 8/2, 199-207.

APEL, Robert, Gary Sweeten, Incarceration, Crime and Employment, Unpublished manuscript, Albany, NY: State University at Albany, 2008.

BARTELS, L.,"The weight of the sword of Damocles: A reconviction analysis of suspended sentences in Tasmania", The Australian and New Zealand J. Of Criminology, 2009, 42/1, 72-100.

BARTON, William H., Jeffrey A. Butts, "Viable Options: Intensive Supervision Programs for Juvenile Delinquents", Crime and Delinquency, 1990, V. 36, N. 2, 238-256.

BECCARİA, Cesare, Suçlar ve Cezalar Hakkında, Çev. Sami Selçuk, Ankara, İmge Kitabevi, 2013.

BENNETT, Trevor, HOLLOWAY, Kathy, FARRINGTON, David, The Effectiveness of Neigborhood Watch, Campbell Systematic Reviews, 2008: 18.

BERGMAN, G.R., The evaluation of an experimental program designed to reduce recidivism among second felony criminal offenders, Wayne State Universitu, Detroit (Mich.), PhD dissertation, 1976.

BOERINGER, Scot, Constance L. Shehan, Ronald L. Akers, "Social context and social learning in sexual coercion and aggression: Assesing the contribution of fraternity membership", Family Relations, 1991, 40, 558-564, nakleden Akers, 2009: 104.

BONTREGAR, R. S., E. K. Winokur, G. Hand, S. Chapman, “Juvenile Justice Interventions: System escalation and effective alternatives to residental placement", Journal of Offender Rehabilitation, 2013, 52/5, 358375.

COOLEY, Charles Horton, Human Nature and Social Order, NewYork: Scribner, 1902 nakleden Akers \& Sellers, 2009.

DURKIN, Keith F., Timothy W. Wolfe, Gregory A. Clark, ““'College students and binge drinking: An evaluation of social learning theory", Sociological Spectrum, 25, 2005, 255-272.

ERDEM, Mustafa Ruhan, Kısa Süreli Özgürlüğü Bağlayıcı Cezaların İnfazı ve Yeni Seçenekler, İnfaz Hukukunun Sorunları Sempozyumu, Ankara: Başkent Üniversitesi, Öz-Özen Matbaa, 1993 s. 192-214.

ELLIS, Lee \& Anthony Walsh, "Criminologists' opinions about causes and theories of crime and delinquency", The Criminologist, 1999, 24 (4):1, 4-6, nakleden Akers \& Sellers, 2009. 
FARRINGTON, D. P., \& Petrosino, A., The Campbell Collaboration Crime and Justice Group. The Annals of the American Academy of Political and Social Academy of Political and Social Science, 2001, 578, 35-49.

GARRIDO, Vicente, QUINTRO, Luz Anyela Morales, Serious (Violent and Chronic) Juvenile Offenders: A Systematic Review of Treatment Effectiveness in Secure Corrections, Campbell Systematic Reviews, The Campbell Collaboration Library, 2007.

GENDREAU P., Goggin, C., \& Cullen, F, The effects of prison sentences on recidivism. A report to the Corrections Research and Development and Aboriginal Policy Branch, Solicitor General of Canada. Ottawa, Ontario: Public Works \& Government Services Canada, 1999.

GENDREAU, P., Goggin, C., \& Fulton, B., Intensive probation in probation and parole settings, In C. R. Hollin (Ed.), Handbook of Offender Assessment and Treatment (pp. 195-204). Chichester, UK: John Wiley \& Sons Ltd., 2000.

GENDrEAU, P., Goggin, C., Cullen, F. T., \& Andrews, D. A., The effects of community sanctions and incarceration on recidivism, In Compendium of Effective Correctional Programs (volume 1, chapter 4). Ottawa, Ontario: Correctional Service of Canada, Solicitor General of Canada, 2001.

GÜVEL, Enver Alper, Suç ve Ceza Ekonomisi, Ankara: Roma Yayınları, 2004.

İÇEL, Kayıhan ve diğerleri, Yaptırım Teorisi, İstanbul: Beta Basım Yayım, 2000.

KARAKAŞ-DOĞAN, Fatma, Kuzey Kıbrıs (KKTC) Merkezi Cezaevi Üzerinde Yapılan Alan Çalışmasından Elde Edilen Verilerin Suçla Mücadele Bağlamında Analizi, TBB Dergisi, 2012 (100), 97-151.

KIZMAZ, Zahir, Cezaevinin ve Hapsetmenin Suçu Engellemedeki Etkisi, Dumlupınar Üniversitesi SBD, 2007 (17), 44-68.

KILLIAS M., Aebi M., RIBEAUD, D., Does community service rehabilitate better than shorter-term imprisonment? Results of a controlled experiment. Howard Journal of Criminal Justice, 39/1, 2000, 40-57.

KRAUS, J., "A comparison of Corrective Effects of Probation and Detention on Male Juvenile Offenders", British Journal of Criminology, V. 14, N. 1, 1974, 49-62;

, "Remand in Custody as a Deterrrent in Juvenile Jurisdiction", British Journal of Criminology, V. 18, N. 3, 1978, 285-289;

---------, "The Effects of Committal to a Special School for Truants", International Journal of Offender Therapies and Comparative Criminology, V. 25, N. 2, 1981, 130-138.

LEE, Gang, Ronald L. Akers, Marism Borg, "Social learning and structural factors in adolescent substance use", Western Criminology Review, 2004, 5, 17-34, nakleden Akers, 2009: 104.

LITTEL, J. H., Corcoran, J., \& Pillai, V., Systematic reviews and meta-analysis. New York, NY: Oxford University Press, 2008.

LOUGHRAN, Thomas A., Edward P. Mulvey, Carol A. Schubert, Jeffrey Fagan, Sandra H. Losoya, Alex R. Piquero, "Estimating a Dose-Response Relationship between Length of Stay and Recidivism in Serious Juvenile Offenders", Working Paper, Pittsburgh: University of Pittsburgh Medical Center, 2008.

LUM, Cynthia, KENNEDY, Leslie W., SHERLEY, Alison J., The Effectiveness of Counter-Terrorism Strategies, Campbell Systematic Reviews, The Campbell Collaboration Library, 2006.

MacIVOR, G., "Community service and custody in Scotland”, The Howard Journal, 1990, 29/2, 101-113.

MacKENZIE, D. L., SHAW, J.W.: The impact of shock incarceration on technical violations and new Criminal activities, Justice Quartely, 1993, 10/3, 463-487.

McDOUGALl, Cynthia, COHEN, Mark. A., SWARAY, Raymond ve PERRY, Amanda, "The Costs and Benefits of Sentencing: A Systematic Review, The Annals of the American Academy of Political and Social Science", Assessing Systematic Evidence, Crime and Justice: Methodological Concerns and Empirical Outcomes (May, 2003), V. 587, pp. 160-177.

MCDOUGALL, Cynthia, COHEN, Mark A. PERRY, Amanda, SWARAY, Raymond, Benefit-Cost Analyses of Sentencing: A Systematic Review, Campbell Systematic Reviews, The Campbell Collaboration Library, 2008 . 
MEAD, George Herbert, Mind, Self, and Society, Chicago: University of Chicago Press, 1934, nakleden Akers\& Sellers, 2009: 152.

MEARS, Daniel P., Coachran, Joshua C., Cullen, Francis T., "Incarceration Heterogeneity and Its Implications for Assessing the Effectiveness of Imprisonment on Recidivism", Criminal Justice Policy Review, 24 April 2014.

MITCHELL, Ojmarrh, MACKENZIE, Doris,WILSON, David, The Effectiveness of Incarceration-Based Drug Treatment on Crime Behavior: A Systematic Review, Campbell Systematic Reviews, The Campbell Collaboration Library, 2012.

MUILUVUORI, M.L.,"Recidivism amog people sentenced to community service in Finland", Journal of Scandinavian Studies in Criminology and Crime Prevention, 2/7, 2001, pp. 72-82.

MURRAY, Joseph, FARRINGTON, David,SEKOL, Ivana, OLSEN, Rikke F., Parental Imprisonment: A Systematic Review of Its Effects on Child Antisocial Behavior, Crime and Mental Health, Campbell Systematic Reviews, The Campbell Collaboration Library, 2009.

NAGIN, Daniel S., Francis T. Cullen ve Cheryl Lero Jonson, "Imprisonment and Reoffending", Crime and Justice, Vol. 38, No. 1, 2009, 115-200.

NAGIN, Daniel S., Deterrence: Scaring offenders straight. In F. T. Cullen \& C. L. Jonson (Eds.), Correctional Theory: Context and Consequences (pp. 67-98). California, CA: Sage. 2012.

NIEUWBEERTA P., NAGIN D., BLOKLAND A., Assessing the impact of first-time imprisonment on offenders' subsequent criminal career development: A matched samples comparison. Journal of Quantitative Criminology, 25,2009, 227-257.

PETERSILIA, Joan, Susan Turner, Judith Peterson, Prison versus Probation in California: Implications for Crime and Offender Recidivism, Santa Monica, CA: RAND Corporation, 1986.

PETROSINO, Anthony, BUEHLER, John,TURPIN-PETROSINO, Carolyn, Scared Straight and Other Juvenile Awareness Programs for Preventing Juvenile Delinquency: A Systematic Review, The ANNALS of the American Academy of Political and Social Science, V. 589, N. 1, 2003, 41-62.

SAVOLAINEN, Jukka, Wayne Nehwadowich, Aida Teharatchi ve Bernice LinenReed, Criminal Recidivisim among Felony-Level ATI Program Participants in New York City, New York City Criminal Justice Agency, 2002.

SCHNEIDER, Anne L., "Restitution and Recidivism Rates of Juvenile Offenders: Results from Four Experimental Studies", Criminology, V. 24, N. 33, 1986, 533,552.

SKINNER, William F., A. M. Fream, "A socail learning theory analysis of computer crime among college students", Journal of Research in Crime and Delinquency, 1997, 34, 495-518 nakleden Akers, 2009.

SIMPSON, Sally, RORIE, Melissa, ALPER Mariel Elise, SCHELL- BUSEY Natalie, LAUFER William, N. Craig Smith, "Corporate Crime Deterrence A Systematic Review", The Campbell Collaboration Library, 01.05.2014.

SMITH, P., Ronald L. Akers, "A Comparison of Recidivism of Florida's Community Control and Prison: A Five-Year Survival Analysis" Journal of Research in Crime and Delinquency, V. 30, N. 3, 1993, 267292.

SMITH, P., GOGGIN, C., GENDREAU, P., The effects of prison sentences and intermediate Sanctions on Recidivism: General effects and individual differences, Canada Public Works and Government, 2002.

STITT, B., Grant ve David. J. Giacopassi, "Trends in the connectivity of theory and research in criminology", The Criminologist, 1992, 17:1, 3-6, nakleden Akers \& Sellers, 2009.

STRANG, Heather, SHERMAN, Lawrence W.,MAYO-WILSON, Evan, Restorative Justice Conferencing (RJC) Using Face-to-Dace Meetings of Offenders and Victims: Effects on Offender Recidivism and Victim Satisfaction, A Systematic Review, Campbell Systematic Reviews, The Campbell Collaboration Library, 2013. 
TOPÇUOĞLU, Tuba, “Türkiye’de Suçluluğa ve İnfaz Politikalarına İlişkin Veri İhtiyacı”, CHKD, Cilt:3, Sayı: 1, 2015 (b), s. 167-191.

TOPÇUOĞLU, Tuba, “Türkiye'de Denetimli Serbestlik Hizmetlerinin Etkinliğinin Bilimsel Olarak Değerlendirilmesi”, Türkiye'de Denetimli Serbestlik 10. Yıl Sempozyumu, 8-10 Aralık 2015 (a), İstanbul, s.1-16.

TOPÇUOĞLU, Tuba, “Ceza İnfaz Kurumlarında Gerçekleştirilen Madde Bağımlılığı Programlarının Etkinliği: Meta-Analiz Çalışmaların Sistematik Olarak İncelenmesi”, Addicta: The Turkish Journal on Addictions, 30. 06. 2016, s. 87-125.

Van der WERFF, C., Speciale Preventie, Den Haag: WODC, 1979.

WEISBURD, David, Elin Waring ve Ellen Chayet, "Spesific Deterrence in a Sample of Offenders Convicted of White-Collar Crimes", Criminology, V. 33, N. 4, 1995, 587-607.

WEISBURD, David, Elin Waring ve Ellen Chayet, White-Collar Crime and Criminal Careers, Cambridge University Press, 2001.

WERMINK, H., BLOKLAND, A.,NIEUWBEERTA, P., NAGIN D., TOLLNAAR, N., "Comparing the effects of community service and short-term imprisonment on recidivism: a matched samples approach", J. Exp. Crime, 6/3, pp. 326-349.

WHITE, Rob \& HAİNES Fiona, Crime \& Criminology, Oxford University Press, 4. Edition, 2008.

WILSON, David B., MACKENZIE, Doris L.,MITCHELL, Fawn Ngo: Effects of Correctional Boot Camps on Offending, Campbell Systematic Reviews, The Campbell Collaboration Library, 2005.

WINFREE, L. Thomas, Christine Sellers, Dennis L. Clason: "Social learning and asolescent deviance abstention: Toward understanting reasons for initiating, quitting, and avoiding drugs", Journal of Quantiative Criminology, 1993, V. 9, 101-125.

VISHER, Christy, COGGESHALL, Mark B.,WINTERFIELD, Laura, Systematic Review of Non-Custodial Employment Programs: Impact on Recidivisim Rates of Ex-Offenders, Campbell Systematic Reviews, The Campbell Collaboration Library, 2006.

VILlETtAZ, Patrice, GILliERON Gwladys, KILLIAS, Martin: The Effects on Re-offending of Custodial vs. Non-custodial Sanctions:An Updated Systematic Review of the State of Knowledge, Campbell Systematic Reviews, 2015. 